Bryn Mawr College

Scholarship, Research, and Creative Work at Bryn Mawr College

Graduate School of Social Work and Social

Graduate School of Social Work and Social

Research Faculty Research and Scholarship

Research

2013

\title{
Individual and Collective Dimensions of Resilience within Political Violence
}

Cindy A. Sousa

Bryn Mawr College, csousa@brynmawr.edu

Muhammad M. Haj-Yahia

Guy Feldman

Jessica Lee

Let us know how access to this document benefits you.

Follow this and additional works at: http://repository.brynmawr.edu/gsswsr_pubs

Part of the Social Work Commons

\section{Custom Citation}

Sousa, Cindy A., Haj-Yahia, Muhammad M., Feldman, Guy, and Lee, Jessica, "Individual and Collective Dimensions of Resilience Within Political Violence," Trauma, Violence, and Abuse, 14.3 (2013), pp. 235-254.

This paper is posted at Scholarship, Research, and Creative Work at Bryn Mawr College. http://repository.brynmawr.edu/gsswsr_pubs/54

For more information, please contact repository@brynmawr.edu. 


\begin{abstract}
Research has documented a link between political violence and the functioning of individuals and communities. Yet, despite the hardships that political violence creates, evidence suggests remarkable fortitude and resilience within both individuals and communities. Individual characteristics that appear to build resilience against political violence include demographic factors such as gender and age, and internal resources such as hope, optimism, determination and religious convictions. Research has also documented the protective influence of individuals' connection to community and their involvement in work, school or political action. Additionally, research on political violence and resilience has increasingly focused on communities themselves as a unit of analysis. Community resilience, like individual resilience, is a process supported by various traits, capacities, and emotional orientations towards hardship. This review addresses various findings related to both individual and community resilience within political violence and offers recommendations for research, practice, and policy.
\end{abstract}




\section{Introduction}

Political violence is the deliberate use of power and physical force to achieve political goals (United Nations Development Program (UNDP), 2012), as with wars, armed conflicts, repressive dictatorships, and military occupations (United Nations Development Program (UNDP), 2012; Zwi \& Ugalde, 1989). As outlined by the World Health Organization (WHO) (2002), political violence includes physical or psychological acts that harm or intimidate populations, such as shootings or aerial bombardments; detentions, arrests and torture; and home demolitions (Basoglu, Livanou, \& Crnobaric, 2005; Clark et al., 2010; K. de Jong et al., 2002; E. F. Dubow et al., 2010; Farwell, 2004; Giacaman, Shannon, Saab, Arya, \& Boyce, 2007; Hobfoll, Hall, \& Canetti, 2012). The WHO definition of political violence also includes deprivation, or the intentional manipulation of power with the goal of prohibiting specific populations from realizing basic needs and human rights; examples are the repression of rights to freedom of speech, and denial of access to food, education, sanitation and healthcare (International Committee of the Red Cross (ICRC), 1949; UNESCO, 2006; UNESCO: International Program for the Development of Communication (IPDC), 2012; United Nations Population Fund, 2007).

The experience and effects of political violence are highly context specific, as the duration and magnitude of political violence, people's proximity to the violence and the subjective meaning of political violence vary from place to place and from person to person (Barber, 2008, 2009; Sagi-Schwartz, 2008). For instance, some situations of political violence are relatively brief, while others are prolonged. Examples of prolonged political violence include decades of repression through surveillance, disappearances of 
community activists, massacres and assassinations (as seen in Argentina during the “Dirty War" from 1976-1983 (Robben, 2005)) and ongoing military occupations of civilian areas wherein movement is restricted and residents endure constant threat of army raids within neighborhoods and personal homes (as seen in Afghanistan and Palestine (Fluri, 2011; Giacaman, Shannon, et al., 2007)).

Political violence represents a somewhat unique stressor in that it threatens both individuals and their environments (Hoffman \& Kruczek, 2011; Martín-Baró, Aron, \& Corne, 1994; Martinez \& Eiroa-Orosa, 2010; Nelson, 2003; Robben, 2005; Summerfield, 2000). Research has connected political violence to a range of poor physical and mental health outcomes for civilian populations (Basoglu, Livanou, \& Crnobaric, 2005; Sidel, 2008), destruction of community functioning (Dillenburger, Fargas, \& Akhonzada, 2008; Pedersen, Tremblay, Errazuriz, \& Gamarra, 2008; Skidmore, 2003), and deterioration of government systems (Basu, 2004; Sidel \& Levy, 2008). Political violence disproportionately affects lower income countries, increasing poverty and dependence and weakening vulnerable infrastructures, often resulting in near-collapse of civil society and the loss of functional legal and healthcare systems (Baingana, Bannon, \& Thomas, 2005).

In addition to growing evidence about the problems resulting from political violence, there is also emergent evidence that individuals and communities tend to somehow effectively manage the stressors of political violence, exhibiting substantial resilience as they demonstrate much more positive functioning than might be expected (Summerfield, 1999). Accordingly, there is a small but growing body of literature suggesting that, within political violence, as with other stressors, resilience may very well 
be a part of a normal, expected course of adaptation to trauma for both individuals and communities (Bonanno, 2004; F. Norris, Stevens, Pfefferbaum, Wyche, \& Pfefferbaum, 2008).

The concept of resilience, as applied to both individuals and communities, while the subject of much scholarship in the past several decades, is still not fully comprehended nor easily defined (Klika \& Herrenkohl, under review; Panter-Brick \& Eggerman, 2012). There is, however, general agreement that the concept of resilience, which has been applied to both individual and community levels, signifies the successful recovery from or adaptation to the adversity of stress (any disruptive life event that requires some form of response or adjustment (Clark, et al., 2007)) through the use of individual or community characteristics, resources, strategies, and processes (Agaibi, 2005; F. Norris, et al., 2008). Scholars increasingly assert that resilience must be understood within a framework that prioritizes the dynamic interaction between individuals and their social and political environments; seen this way, well-being depends on both individual and environmental factors (Betancourt \& Khan, 2008; Shinn \& Toohey, 2003; Ungar, 2011b; World Health Organization, 2008).

This review details and discusses findings about both individual and community resilience within the context of political violence, addressing several interrelated questions: What does research on political violence tell us about factors or processes of resilience within both individuals and communities? What do findings about resilience in settings of political violence suggest about the relationship of individuals to communities; and in particular, within scholarship on political violence, are there examples of systematic investigations of the connections between individual and community 
resilience? How do findings about political violence and resilience inform research and intervention within the separate, but connected, fields of political violence and resilience?

In line with these three research questions, we first address individual traits, skills, and processes related to resilience within the context of political violence. Findings on resources that promote resilience within individuals' social environments, including family and political contexts are also reviewed. Then, we present emerging evidence about how resilience operates on the level of the community within contexts of political violence. We conclude with a summary of the findings, a discussion on the methodological and ethical challenges in terms of political violence and resilience, and an assessment of the implications for both research and practice.

\section{Methods}

As others have pointed out (Klika \& Herrenkohl, under review), there is considerable discussion about the term resilience and how it relates to protective factors. Within this review, we include findings related to both resilience and protective factors, with the understanding that analyses of protective factors_-variables that include characteristics as well as processes that lessen risk and/or promote well-being — can help establish when and under which conditions resilience can develop (Herrenkohl, 2011). We searched the PsychInfo and PubMed databases using the key terms "political violence + resilience [or] protective factors" and "war + resilience [or] protective factors" and "disasters + community resilience.” After examining abstracts, we kept articles for further analysis if they met the search criteria in that they both (1) focused on civilian populations living within contexts of political violence and (2) addressed one or more of the questions posed 
above. This resulted in fourty-nine articles that were retained for analysis. Forty-one articles focused on aspects of individual resilience and eight focused on community resilience. The review utilizes an integrated design to examine quantitative, qualitative, and mixed-methods studies; this integrated design was chosen because of the potential for findings from across study designs to collectively advance knowledge about political violence and resilience (Voils, Sandelowski, Barroso, \& Hasselblad, 2008). For more information about the types of methods used across studies (e.g., surveys, narrative research, ethnography/case study; mixed methods, longitudinal), see Table 1. Readers should note the categories of methods are not mutually exclusive; if the study used multiple methods, all methods are represented in the table. Table 1 also details the study locations, the characterization of political violence by the author, and the source of data (population description where appropriate or site for case study/ethnographic work).

Our search criteria resulted in studies that represented the diverse experiences present in the field of research on political violence. These experiences ranged from encountering direct, physical consequences of warfare, to experiencing political violence more indirectly, such as suffering from the effects of political violence on economic and social structures. This review focuses on civilians and does not address soldiers, veterans, or Prisoners of War (POWs); others have provided reviews of resilience within these populations (Agaibi, 2005). This review discusses resilience in the context of political violence for both children and adults (for overviews of resilience within political violence focusing on children specifically, see (Betancourt \& Khan, 2008; Elbedour, ten Bensel, \& Bastien, 1993)). 


\section{Findings}

\section{Individual traits, skills and processes}

Scholars have found a range of traits and skills that are associated with individuals' resilience when faced with political violence. These include demographic characteristics, such as age and gender, as well as attributes and skills, such as help-seeking behaviors; values, such as religious beliefs; and emotional orientations, such as hope and optimism. Scholarship also provides evidence about how individuals apply thought processes to build resilience. For instance, individuals must go through a process of meaning-making, wherein they work to resolve the challenge that the maliciousness of political violence poses to their previously held understandings of how the world works (Janoff-Bulman, 1992). The following discussion examines these areas of individual-level resilience (traits, skills and processes) separately for children and adults.

\section{Children.}

Evidence is mixed regarding the role of gender and resilience in the face of political violence. This ambiguity about gender and resilience might be due, in part, to how gender affects the array of outcomes used to consider the effects of political violence. There is some evidence that girls exhibit fewer problem behaviors than boys after exposure to the same amount of political violence (Garbarino and Kostelny, 1996). Other studies, however, found girls to be more vulnerable to negative outcomes, demonstrating more PTSD and stress and less Post-Traumatic Growth (positive change resulting from adversity) (Kimhi, Eshel, Zysberg, \& Hantman, 2010; Qouta, Punama $\square$ ki, \& El Sarraj, 
2003). Still other studies have shown that males and females exhibit similar levels of resilience (E. F. Dubow, et al., 2010; Laor et al., 2006).

The ways in which males and females experience political violence must be considered when looking at the question of resilience and gender, as this might be a reason for the discrepancy in outcomes across genders. For instance, although the authors of one study of children in Lebanon did not find gender to moderate the relationship between political violence and mental health, they did find that boys reported a higher number of war experiences in comparison to girls (Macksoud \& Aber, 1996). The authors suggest a few reasons why this might have occurred, including that girls might be easier to control and protect, or were more apt to follow safety instructions and to be kept at home or inside during the fighting. Authors also noted that girls are more apt to be sent away to safer regions, whereas boys are kept at home to assist the family. Similarly, in a study in Gaza, Barber (2008) found that boys experienced far higher rates of direct political violence than girls, perhaps due to their increased involvement in political activity in comparison to girls; nearly two-thirds of boys reported that they had been hit or kicked by soldiers and one-quarter reported that they had been imprisoned. Giacaman (Giacaman, Shannon, et al., 2007) also found that girls reported less exposure to political violence overall than boys (although they reported more symptoms of depression than boys). Other researchers have not found differences in exposure to political violence based on gender (Haj-Yahia, 2008).

As evident in the dynamics discussed above, research seems to highlight that boys and girls might experience political violence differently, perhaps related to gender-based norms and patterns of society. For instance, Garbarino and Kostelny (1996), who studied 
the accumulation of risks across both political violence and family violence found that girls seem to fare better than boys when faced with increasing levels of violence; these authors suggest the ways in which gender norms play out may have interacted with the events of the political violence so that girls were actually offered more opportunities for resilience. Specifically, Garbarino and Kostelny propose that conflict-related upheaval and chaos leads to less supervision and more freedom; authors posit this increased independence may foster resilience among girls while posing a risk to boys. Discussions about the role of gender within political violence might do well by not focusing on who is more resilient (boys or girls), but rather about how risk and resilience might manifest differently for boys and girls (Barber, 1999, 2001; Laor, et al., 2006; Punama $\square$ ki, Qouta, \& El-Sarraj, 2001). Haj-Yahia (2008), for instance, found that in the face of political violence girls showed more internalizing symptoms, whereas boys showed more externalizing symptoms.

As with gender, findings are mixed regarding the role the age of a child plays in resilience. Some findings indicate no connection between political violence and mental health outcomes due to children's ages (E. F. Dubow, et al., 2010 ; Qouta, et al., 2003). Other results suggest that older children may be somewhat more protected from the effects of political violence than younger children; perhaps due to the presence of a longer pre-conflict period of normalcy or due to advances in children's developmental trajectories, including increased abilities to process or make sense of political violence (Betancourt, 2011; Garbarino \& Kostelny, 1996; Kuterovac-Jagodic, 2003; Qouta, et al., 2003). In contrast, two separate studies with Israeli adolescents found younger children actually had better mental health outcomes in the face of political violence (Kimhi, et al., 
2010; Laor, et al., 2006). The finding that increasing age may impair resilience aligns with theories about the effects of chronic stress which posit that while body stress responses are initially adaptive, when stress responses remain consistently active, physiological reactions become maladaptive and cause wear and tear on the body (Geronimus, Hicken, Keene, \& Bound, 2006; McEwen, 2000).

Discussions about the role of age in terms of political violence and resilience should perhaps attend to how exposure to political violence varies according to age, rather than age alone as a protective factor. For instance, in one study, researchers found older children experienced a larger proportion of war traumas in comparison to younger children (Macksoud \& Aber, 1996). Furthermore, understanding the role that age might play within resilience related to political violence requires more than simply comparing rates of negative outcomes resulting from political violence across age groups. It requires looking at developmental differences that might account for shown differences. For example, Kuterovac $\square$ Jagodić (2003), in research on political violence among Croatian children, compared coping strategies among children along six types of strategies, including aggressive acts, acts aimed at distraction, and problem-oriented strategies. These authors found younger children tended to use more strategies of distraction than older children, whereas older children tended to cope by employing aggressive strategies. Research has also examined whether family level factors, such as demographics, mental health, or place of residence, might offer some protection from the stress of political violence. Findings are quite mixed regarding the influence of parents' level of education, with some authors finding no influence on children's adjustment to political violence (Macksoud \& Aber, 1996). Other studies show disparate findings: one found 
increased symptoms among children whose fathers had a lower educational status (HajYahia, 2008) and another study found a positive relationship between children's PTSD and mother's level of education (Quota, et al., 2003). Quota, et al. (2003) theorize two possible explanations for this: more highly educated mothers might encounter more political violence as they may be more likely to work outside the home and, or more highly educated women might be inclined to discuss children's symptoms with their children, thus increasing children's reports of symptoms to interviewers. With regards to other family demographics, higher economic or occupational status may be protective (Kimhi, 2010; Macksoud \& Aber, 1996) and mother's mental health may significant influence children's outcomes related to political violence (Cummings, et al., 2009; Quota, et al., 2003).

Area of residence has also been considered as a variable that might change resilience trajectories for those exposed to political violence. In two studies, youth in rural areas and refugee camps had poorer mental health and behavioral outcomes than youth who lived in urban areas (Giacaman, Shannon, et al., 2007; Haj-Yahia (2008). Differences in regional demographics might account, at least in part, for poorer outcomes; two authors found differences in the magnitude of political violence, including extreme deprivation, and differences in political violence related emigration based on children's area of residence (Giacaman, Shannon, et al., 2007; Macksoud and Aber, 1996).

In addition to demographic characteristics, children's values and beliefs; temperament and emotional orientations; and cognitive and social skills seem to facilitate their positive adjustment in the face of political violence. Strong religious 
conviction has long been recognized as an important component of resilience for youth; the importance of religious beliefs is also evident for youth in settings of political violence (Barber, 2001; Eggerman \& Panter-Brick, 2010).Studies with children from places such as Afghanistan, Bosnia, Colombia, and Eritrea all conclude that hope, determination, and agency facilitate an orientation towards the future and foster senses of optimism and control that enable children to endure hardships (Berk, et al., 1998; Cortes \& Buchanan, 2007; Eggerman \& Panter-Brick, 2010; Farwell, 2001). Cognitive capacity and intelligence also appear to protect children from the effects of political violence, as do affect regulation (including the ability to remain calm in adversity) and a sense of humor (Berk, 1998; Cortes \& Buchanan, 2007; Gibson, 2002; Qouta, Punama $\square$ ki, Montgomery, \& Sarraj, 2007). Illustrating the importance of both future-orientation and cognitive capacity, children's ability to constructively plan for their safety may be key to their physical and emotional well-being in contexts of political violence (Cortes \& Buchanan, 2007; Farwell, 2001). For instance, female child soldiers in Colombia established partner relationships to avoid being indiscriminately used as sexual slaves (Cortes \& Buchanan, 2007).

In sum, regarding children, the role of demographic factors, including gender, age, and family characteristics, appears to be unresolved within the literature on political violence and resilience. There exists a need for more research that considers not only the facts of these demographic characteristics, but the mechanisms through which they work. It is clearer that certain individual temperament, values, emotional orientations, and skills appear to be protective, such as humor, religious conviction, a sense of agency, future orientation and an ability to regulate affect. 


\section{Adults.}

Relative to the research on children and resilience within the context of political violence, fewer studies focus on political violence and resilience in adults. Findings are less in number but more consistent across studies; for instance, three separate studies each found older adults fared better than younger adults in the face of political violence (Hobfoll, Mancini, Hall, Canetti, \& Bonanno, 2011; Khamis, 1998b; Kimhi, 2010). Stronger economic conditions also seems important for adults' adjustment to and recovery from political violence (Khamis, 1998b; Kimhi, et al., 2010). Women's educational level might also offer some degree of psychological protection from the effects of political violence (Khamis, 1998b). In addition, several studies found that males demonstrated more resilience than females (Hobfoll, et al., 2011; Kimhi, 2010). Consistent with, and perhaps one explanation for, the findings regarding how males seem to fare better in the face of political violence than females, one study found that women and men who were exposed to political violence experienced social support differently: men experienced high satisfaction with social support, whereas women experienced social support as inadequate and insufficient (Punama $\square$ ki, Komproe, Qouta, El-Masri, \& de Jong, 2005). This suggests that, just as our findings with youth illustrated, beyond simple gender differences, we need to investigate the distinct ways in which males and females might experience factors related to risk and resilience within political violence.

Eggerman and Panter-Brick (2010) found that religious conviction, including giving ones' fate over to a higher power, was a common coping process used among adults. Service, perseverance, and effort were also all core components of coping among adults in Afghanistan; in part, this may be due to the relationship ascribed by participants 
between these values and economic well-being, which respondents identified as central to overcoming the effects of war (Eggerman \& Panter-Brick, 2010). Though fewer in number than studies addressing personality traits among youth, studies of adults similarly conclude self-esteem; senses of hope and optimism; and processes of problem solving are protective and build empowerment within the face of political violence (Hernández, 2002; Lee, et al., 2008; Shalhoub-Kevorkian, 2006).

Research with adult survivors of torture and other war trauma found that coping styles employed by participants made a difference in how effectively they were able to use cognitive processes to manage the stressors of war. For example, in examining how coping styles interacted with the cognitive process of appraising war trauma as controllable, participants who favored a withdrawal coping style showed more PTSD symptoms than did the participants did not tend to withdraw. Furthermore, a disengaged coping style interacted with cognitive processes so that, for example, people who viewed situations to be controllable but who relied on a disengaged coping style were more at risk for mental health symptoms (Hooberman, Rosenfeld, Rasmussen, \& Keller, 2010). This suggests additional attention should be paid to the ways in which individuals use emotional and cognitive strategies to withstand the effects of political violence.

Studies of adult resilience within political violence provide results consistent with those from studies of children, demonstrating the protective influence of personal traits and values like optimism and religious conviction. More literature exists about adults than about children regarding the importance of processes of meaning making, a central process within coping (Lazarus, 2000; Ursano, Fullerton, \& McCaughey, 1994). For instance, Hernández (2002) reported that, among human rights activists targeted with 
political violence in Colombia, taking part in meaning-making processes within the context of trusting relationships (i.e. understanding the political nature of the atrocities and working for peace and justice) allowed survivors to develop a sense of internal coherence. Eggerman and Panter-Brick (2010) found that cultural values such as service, morals, and honor helped adults in Afghanistan to make sense of violence experiences and thus endure war. Although this literature appears to still be in its early stages, studies among adults seem to agree on the positive outcomes of attempts to cognitively resolve the considerable dissonance that political violence creates as the maliciousness and evil of the experiences, and its massive scale challenges people's previously held notions of justice and human decency (Janoff-Bulman, 1992; Koopman, 1997; Robben, 2005).

\section{Resources available within the environment}

Scholars have proposed that one of the keys to understanding how resilience operates, whether associated with the effects of political violence or violence in other forms (e.g., community violence, child abuse), is to examine it within a framework that prioritizes the dynamic interaction between individuals and their environments (Fraser, Kirby, \& Smokowski, 2004; Ungar, 2011b). For both children and adults, resilience within contexts of political violence appears to be closely related to the resources available in the surrounding environment--families, communities, and greater social and political contexts (what researchers refer to as social ecology) (Betancourt \& Khan, 2008).

\section{Family resources.}

Positive family functioning seems to offer at least some degree of protection for children from the effects of political violence (Barber, 1999; Berk, 1998; Cummings, Goeke- 
Morey, Schermerhorn, Merrilees, \& Cairns, 2009; Garbarino \& Kostelny, 1996; NguyenGillham, Giacaman, Naser, \& Boyce, 2008; Thabet, Ibraheem, Shivram, Winter, \& Vostanis, 2009), although one study of the effects of war on aggression and prosocial behavior among Croatian children did not find that positive parenting had a protective effect (Kerestes, 2006). Core components of the family that appear to build resilience for children affected by political violence include: family support (Farwell, 2001; NguyenGillham et al., 2008; Thabet, et al., 2009); parental acceptance (Barber, 2001); family stability (Berk, 1998); and family cohesion, family functioning, and secure parent-child relationships (Cummings et al., 2009). Findings from one study indicates that family support at least is not a one-dimensional concept; some youth said when there was too much discussion about the political situation, this process within families became counterproductive (Nguyen-Gillham, et al., 2008). There is some evidence that the protective function of parenting may diminish as children age; Quota et al. (2007) theorized the lack of correlation between parenting and mental health symptoms among older Palestinian adolescents may be because of the fading importance of parenting as children grow up.

The family also is an important protective resource for adults facing political violence. Khamis' 1998 study of Palestinian women tested the importance of family relationships within the trajectory of political trauma and mental health. The study showed the level of a family's social-psychological resources was inversely related to psychological distress among traumatized women. This study also demonstrated the level of family hardiness (indicators included coordinated commitment, confidence, challenges, and control) was negatively related to psychological distress and positively related to 
well-being for this group (Khamis, 1998c). In Eggerman et al.'s study among students and caregivers in Afghanistan, family unity, particularly across generations, supported multi-generational economic success, which was central to adult participants' well-being within the context of war (Eggerman \& Panter-Brick, 2010).

\section{Social resources outside the family}

Scholars of resilience have moved the concept beyond simple lists of internal traits; instead, resilience is analyzed within perspectives that stress how it ultimately depends on both the practice of individuals' accessing resources within their environments, and of the responsiveness of environment itself (Masten \& Obradovic, 2008; Ungar, 2011b). Factors that operate within the relationship between individuals and their communities to protect individual well-being in the face of political violence include involvement in school, work and political struggles (Barber, 2001; Betancourt, Brennan, Rubin-Smith, Fitzmaurice, \& Gilman, 2010; Khamis, 1998a; Nguyen-Gillham, et al., 2008), and opportunities for connectedness to and acceptance from the community (Berk, 1998; Betancourt, et al., 2010; Cortes \& Buchanan, 2007).

\section{School and work as social resources.}

In the face of an onslaught of stressors related to political violence, merely maintaining daily activities of living can be viewed as an act of resilience. Attending school or work each foster a sense of normalcy and purpose in the midst of chaos. As Nguyen-Gillman et al. (2008) point out, schools and organizations provide much-needed structure and routine within the turmoil of political violence. 
Sustaining school attendance appears to protect children from the negative consequences of political violence. Barber (2001) found integration into schools offered some protection from depression and antisocial behavior for youth in Palestine.

Betancourt et al.'s longitudinal study with former child soldiers in Sierra Leone found youth who were in school had higher levels of adaptive and prosocial behavior, despite the stressors of war (Betancourt, et al., 2010). In Nguyen-Gillham et al.'s study with adolescents in the West Bank (Nguyen-Gillham, et al., 2008), participants regarded education as a tool to counter the ongoing political violence. Among Afghan youth, education represented a pivotal force that would help youth to excel and to cope with political violence and the accompanying poverty (Eggerman \& Panter-Brick, 2010). In Farwell's study among Eritrean youth, youth said the foremost priority within post-war recovery should be the rebuilding of the infrastructure of the society, with particular attention to that of education. These young people also demonstrated tenacity in their quest for education, with many living apart from their families in lean-tos and with scarce provisions to continue their education (Farwell, 2001).

Work appears to be protective for adults, fostering purpose, meaning, and a sense of normalcy when surrounded by the chaos of political violence. Giacaman notes that for her public health program, regrouping the team and embarking on work in the midst of active fighting in the West Bank enabled adults to persevere. Work provided a concrete outlet to investigate the effects of political violence on health and an opportunity for agency, which fostered hope (Giacaman, 2005). Similarly, one Palestinian woman interviewed by Shalhoub-Kevorkian acknowledged work allowed her to use her time 
effectively and cope with the loss of her home, imprisonment of her brothers, and death of her child (Shalhoub-Kevorkian, 2006).

\section{Opportunities for political engagement.}

Some research has found civic and political involvement to be protective within conflict situations. In the few studies that have examined this question, it appears that a political life may endow feelings of empowerment and dignity on both youth and adults, which in turn offers some protection from the harmful effects of political violence.

A handful of studies have examined the role of political engagement among youth facing political violence. One study found Palestinian children who had endured political violence (including experiences like losing family members, being injured, or witnessing night raids) and who took part in activities expressing national pride (flag raisings during the signing of the Peace Accords) exhibited reduced neuroticism and higher self-esteem than children who did not participate (Qouta, Punama $\square$ ki, \& Sarraj, 1995). In a sample of Palestinian youth, Barber (2008) found that activism during political conflict was significantly correlated to a number of positive outcomes, including higher social competence and civic involvement, higher empathy, and lower antisocial behavior.

There are a couple of mechanisms through which political engagement may offer protection within political violence. Berk's study in Bosnia (1998) posits that political participation offers a sense of purpose, avenue for action, and possibility for connection. Political engagement, including political education, may also represent a mode of protecting and promoting national identity (which is often threatened within political violence). The defense of this national identity may be protective as it builds a sense of collective belonging and empowerment. For instance, Farwell's study of Eritrean youth 
emphasized the importance of understanding history and political thought, as youth considered protecting the nationhood of Eritrea to be a high priority within the process of healing from political violence (Farwell, 2001).

Despite findings discussed above, the question of whether political engagement is always protective with regards to political violence is far from resolved in the literature. For instance, among Bosnian youth, Jones and Kafetsios (2005) found disengagement from political processes was actually protective. Barber (1999) found involvement with political struggles might be related to an increase in antisocial behavior and depression, although he notes that the mechanisms through which this happens merit more scrutiny. For instance, he postulates fluctuating cultural norms around level of autonomy and prevailing gender norms at the time of the study may have been at work (Barber, 1999). Another study by Barber (2008) contrasted Palestinian youth and Bosnian youth, finding more Bosnian youth regretted being involved in political struggles than did Palestinian youth. As Barber suggests, the potential for political involvement as a protective factor may vary by the type of conflict and the cultural and political contexts of struggle (Barber, 2008). Accordingly, Punamäki, et al. (2001) found that the protective effects of children's political activity vary alongside the relative danger that is present.

Compared to studies of children, far fewer studies with adults have focused on political activity as a protective factor within the context of political violence. However, findings from one study suggest political engagement may also be protective for adults. In a series of focus groups in Palestine, participants reported that "political freedom, selfdetermination, participation in democratic processes and feeling involved in political 
decision-making" all were central to people's quality of life within the context of political violence (Giacaman et al., 2007).

\section{Opportunities for social support.}

The existence of and ability to access social support is a predominant way both children and adults cope with political violence. In studies with child soldiers, the existence of supportive adults and communities seemed to protect children from the experiences of war (Betancourt, et al., 2010; Cortes \& Buchanan, 2007). Use of social support includes peer support along with support from adults and communities; one study of how youth endure political violence found Palestinian adolescents tended to garner support from friends (Nguyen-Gillham, et al., 2008). Two elements of social support appear important: instrumental support (i.e. tangible items and information) and emotional support (i.e. comfort and encouragement). Highlighting the importance of instrumental support within contexts of political violence, Farwell (2001) found that informal mutual assistance through activities like pooling money and collectively rebuilding destroyed schools helped Eritrean refugee youth. One illustration of the importance of both types of social support is the study of Bosnian children by Berk (1998), whose findings illustrate the importance of role models who can demonstrate both material resilience (e.g. how to meet basic needs such as procuring water) and emotional resilience (e.g. strategies to engender hope and reduce fear). Two longitudinal studies, one among child soldiers in Sierra Leone, and one among Croatian children, underscore the power of social support over time (Betancourt, et al., 2010; KuterovacJagodic, 2003). Kuterovac-Jagodic (2003), in particular, found that social support did not 
affect children's PTSD symptoms during active fighting, but social support was protective over time (Kuterovac-Jagodic, 2003).

Several studies with adults have also demonstrated the importance of social support in building resilience for those affected by political violence (Hobfoll et al., 2011; Khamis, 1993; Lykes et al., 2007). One study illustrates not only the importance of social support, but also the importance of participants' satisfaction with their social support in protecting adults from the mental health effects of exposure to political violence (Punama $\square$ ki, et al., 2005). An additional finding from this study was that high social support partially mediated the relationship between military violence and mental health; military violence increased social support, which decreased mental health symptoms (Punama $\square$ ki, et al., 2005). Building a sense of collectivity and engaging in shared struggle may be a particularly important manifestation of social support; for instance, Shalboub-Kevorkian (2006) described how women's mutual reliance and their rebuilding and reclaiming of physical and symbolic locations of home enabled them to endure closures of roads and areas, bombings, and house demolitions within political violence. Reflecting these findings, a sense of collective belonging not only to community but to country may be an important way that social support builds protection within political violence (Nuttman-Shwartz, 2012).

Findings from a recent study, however, illustrate an alternate theory of the role of social support within contexts of political violence. Taylor et al. (2012) found that social support protected mental health from the negative effects of nonsectarian violence, but exacerbated mental health problems resulting from sectarian (i.e. political) violence. Authors note this finding is in line with a "depletion hypothesis", wherein increased 
interdependence actually increases stress. Communal coping thus represents both advantages and disadvantages for individuals (Lyons, Mickelson, Sullivan, \& Coyne, 1998). The multi-dimensional aspects of shared coping may be particularly acute within political violence; indeed, researchers have found that political violence overwhelms coping resources (Hobfoll, et al., 2011; F. H. Norris \& Kaniasty, 1996).

\section{Culture as a communal resource for resilience.}

Culture (expressed, for instance, through cultural ceremonies) is an important shared collective resource that promotes resilience, particularly within situations of conflict. For instance, various studies have concluded that cultural ceremonies rebuild self-esteem and community acceptance after people have endured atrocities of political violence like war-related rape (Betancourt \& Khan, 2008). Survivors of genocide-rape in Rwanda reported that processes specific to their cultural context (discovered by researchers in survivors' use of culturally-specific words representing concepts like withstanding trauma and reaffirming life after trauma or death) aided those suffering from political violence (Zraly \& Nyirazinyoye, 2010). After observing youth and adult caregivers in Afghanistan, Eggerman and Panter-Brink (2010) concluded that cultural values underlie the sense of hope that was a major resilience factor. However, they also point out that cultural values and pressures can be constrictive; for example, decisions about marriages and expectations based on gender or birth order may limit people's sense of freedom and their ability to control their own lives. These restrictions may curtail the ability of individuals to accomplish the goals they set for themselves, goals they may determine as central to overcoming the hardships of political violence. 


\section{Opportunities for accountability.}

In cases of extreme traumatic stress due to political violence, the opportunity for individuals to assign blame and accountability may be helpful in making meaning of and recovering from the suffering of political violence (Summerfield, 1999). Thus, processes of accountability through communal activities like tribunals and truth commissions take on particular importance in terms of sustaining resilience after political violence (Farwell \& Cole, 2001; Robben, 2005). Lykes et al. studied the criminal and civic trials brought about by adults within Indigenous communities in Guatemala. These researchers concluded that, while participants faced potential threats due to their testimony, the process of testifying endowed them with a sense that they were standing up for accurate representation of the facts of history and thus promoting social justice; this, in turn, endowed participants with a sense of power and helped to maintain a positive self-image (Lykes, et al., 2007).

Resources that promote resilience within political violence include school or work, social support, opportunities for civic and political engagement and avenues for official accountability for atrocities committed during political violence. Individuals can rally these resources, however, only to the degree that they exist within the environment. Attributes of social and political environments themselves are thus important to examine within questions of resilience (Ungar, 2011b); accordingly, the review now turns to the topic of resilience on the level of the community.

\section{Community Resilience}

Individuals are not the only targets of political violence, as the violence is also focused on larger social and political contexts. Political violence threatens resources that 
support the health, skills and knowledge of individuals; the relationships within families, groups, and between individuals and institutions; and the culture and values of a society, including human rights, traditions, social mores (Ager, Strang, \& Abebe, 2005). It is also clear that political violence undermines government systems as it weakens the public sector, deteriorates necessary infrastructure, and threatens socio-democratic processes (Baingana, et al., 2005; Basu, 2004; Sidel \& Levy, 2008).

In the face of political violence, the availability of collective resources is often overwhelmed by the need for them among populations (Hobfoll, et al., 2011). Among populations suffering from political violence, recovery must happen not only within individuals within larger social and political contexts (Almedom \& Summerfield, 2004). Fortunately, the higher structures on which well-being depend represent not only targets of political violence, but also important sources of community resilience, the subject of increased attention in the past decade (Ager, et al., 2005; Farwell \& Cole, 2001).

Community resilience is defined as positive collective functioning after experiencing a mass stressor, such as a natural or human-made disaster (F. Norris, et al., 2008). Like individual resilience, community resilience has been described as a process, not a trait or an end product (Nuwayhid, Zurayk, Yamout, \& Cortas, 2011). However, similar to individual resilience, certain emotional orientations, characteristics and resources appear to develop resilience; these will be discussed below, followed by a discussion of processes having to do with community resilience.

As with individuals, emotional orientations appear to build resilience on the community level, including collective senses of hope, agency, altruism, trust, and patterns of interdependence (Bar-Tal, 2001; Ungar, 2011a; Wyche et al., 2011). Bar-Tal (2001) 
proposes that societies experience and exhibit specific collective emotional orientations as "cultural frameworks," which are established through shared memories, goals, and myths of a society. These collective emotional orientations can be identified by examining cultural products, artifacts of the educational system, society's public discourse, the influence of emotion on institutional decision-making and policies, and widely exhibited individual expressions of the emotion. One important collective emotional state within the context of political violence is a sense of collective security, wherein there is a general sense within the populace that they are either free from danger or that dangers are manageable (Bar-Tal, Jacobson, \& Freund, 1995). Similarly, within protracted political conflict, societies engender collective emotional orientations of either fear or hope; the collective sense of hope is closely linked to resilience and the potential for peace in the face of collective traumas like political violence (Bar-Tal, 2001; Landau $\&$ Saul, 2004; Walsh, 2007). Collective hope and agency are closely linked, as Giacaman (2005) notes regarding the role of resilience in the West Bank. Collective hope motivates communal action and helps to orient individuals and collectives towards the future (BarTal, 2001; Walsh, 2007).

In addition to emotional orientations, community characteristics appear to build the potential for resilience. For instance, in their examination of community resilience in Lebanon following the 2006 war with Israel, researchers concluded that a sense of collective identity and community cohesion as well as a hardiness borne of prior experience with wars contributed to community resilience (Nuwayhid, et al., 2011). Resources within communities, particularly social capital and physical and organizational infrastructure, are important for building collective resilience (Ungar, 
2011a). In fact, community resilience in the face of mass disasters has been conceptualized a set of "adaptive capacities," where the resources of social capital, economic development, information and communication, and community competence all interact (F. Norris, et al., 2008). For instance, educational and health service networks run by trusted leadership were central to the resilience processes among Internally Displaced People (IDPs) in Lebanon during the 2006 war with Israel (Nuwayhid, et al., 2011). Tierney (2003) found that four types of shared resources, technical, organizational, social and economic, facilitated community resilience in the wake of the 2001 attacks on the World Trade Center. Findings also pointed to the specific properties within collective elements and systems necessary to build community resilience; these included robustness (the ability of infrastructure to withstand stress); redundancy (the ability of systems to function in case primary systems are destroyed); resourcefulness (the possibility for mobilization of human and material resources); and rapidity (the timeliness with which priorities are met) (Tierney, 2003).

The literature consistently supports the idea that community resilience depends not only on the number and strength of the resources within a community but on how these resources integrate as networks. Nuwayhid et al. (2011) found health networks protected the well-being of populations during massive displacement, by distributing medical care, clothing, food, water and other provisions. Tierney (2003) noted the importance of networks post 9-11 attacks in the efficient mobilization of resources, both those that existed prior to the attacks and those that were spontaneously formed. While systems of organization helped form workgroups (such as law enforcement, transportation, and human needs), the networks were were informal and operated with 
some degree of autonomy, which allowed flexibility and adaptability. Shalhoub-

Kevorkian, in her research among Palestinian women, described the power of informal networks of women in a community. One of her participants described how the women in the neighborhood divide up the duties: one registers children for school, one obtains permits necessary for movement across checkpoints, one gets medication, one keeps informed and alerts others about roadblocks or other restrictions to movement because of the political conflict, and so on (Shalhoub-Kevorkian, 2006). This type of coordination not only resulted in the women's accomplishing practical tasks, but also built a sense of individual, communal and national identity and steadfastness. Similarly, Robben (2005), who completed an in-depth examination of decades-long repression in Argentina, concludes that efforts to resist and demand accountability moved suffering from the private realm into the public, and gave participants a sense of power over their symptoms of trauma.

Activities related to collective memory of the trauma of political violence also appear to be important in building community resilience (Pennebaker, 1997). For example, Lykes et al. studied the creation of a communal phototext book by twenty adult Indigenous women in Guatemala who generated stories and photographs of massacres, public executions of women, and the assassination of their local priest. It also told of their emotional reactions and their hopes for the future. While initially women came to the project with anxiety, after its completion they spoke of the power of this process for helping them to move past their fear and to reclaim their voices and their sense of collective power, respect and pride. Ultimately, the process told the story of both collective suffering and collective resistance, and seemed to lay the foundation for future 
action through additional projects of community building and defense of the community (Lykes, et al., 2007). In another example, researchers uncovered what they termed “communal proactive coping strategies" that helped Tamil refugees who were survivors of civil war deal with the effects of the war and with resettlement. These communal proactive coping strategies included forming common goals, accumulating shared resources, and establishing new organizations and networks to research and address mental health problems (Guribye, Sandal, \& Oppedal, 2011).

The newly emerging literature on community resilience points to several findings regarding community wellness within the context of political violence. This includes emotional orientations, characteristics and processes that occur on a community level. Of particular importance is the expanding body of literature on aspects of and processes within community-level systems and networks that foster resilience in the face of mass disasters such as political violence.

\section{Conclusion}

Despite the far-reaching and often long-lasting effects of political violence, this review identifies a progressive accumulation of evidence that illustrates how specific characteristics, orientations, resources, and processes on both individual and community levels provide at least some protection against the effects of political violence. Evidence of how people and communities endure political violence helps us understand the dynamic possibilities for endurance and growth within contexts of adversity. These types of studies represent an important move away from analyses of political violence that pathologize populations and remove agency at both individual and collective levels, a 
tendency that has been increasingly criticized in the literature on political violence (Summerfield, 1999). In line with what resilience researchers have long asserted (Bonanno, 2004), scholarship suggests that in the search for mastery over our environments, individuals and communities tend to emerge from political violence with commitments to and capabilities for building wellbeing.

This review set out to examine the current literature on individual and community resilience in the face of political violence. Findings of this review point to several characteristics and processes related to resilience, many of which are common to both the individual and the community. Important characteristics at both individual and community levels were hope, optimism, and the ability to effectively strategize to solve problems. Processes critical for resilience included activities of individual and collective meaning making. Within the community level, processes of building networks were also important.

Among the central tasks of this review was to explore the relationship between individuals and communities with regard to resilience in settings of political violence. Many studies in this review concluded that factors within individuals' larger social and political contexts (such as social support, work or school, and opportunities for political involvement and accountability) promoted individual well-being within political violence. Few studies, however, specifically adopted social ecological perspectives to examine resilience. There is a need for further research on resilience within political violence that uses multi-level frameworks to study protective factors in settings of political violence. This is particularly important for knowledge building about adult populations facing political violence, given that studies are increasingly addressing resilience about children 
and political violence employing social-ecological perspectives (Betancourt \& Khan, 2008; Cummings, et al., 2009; Eric F. Dubow, Huesmann, \& Boxer, 2009; Fazel, Reed, Panter-Brick, \& Stein, 2012).

While a variety of studies demonstrated the importance of the larger sociopolitical context for individual resilience, few studies attended specifically to the ways in which resilience is actually a product of the dynamic and reciprocal relationship between individuals and communities, where resilience on each level is dependent on the other (Ungar, 2011b). This is especially important within collective disasters like political violence, where community resilience and individual resilience are so closely related that disentangling them is unrealistic (Masten \& Obradovic, 2008). One exception is research by Kimhi and Eshel (2009), who found people's recovery from political violence was highly dependent on individuals' perceptions of community resilience (including their estimations of perceptions of the strength and endurance of the community and their trust in leadership). Another exception is the study by Hernández (2002), whose results emphasize how relationships among individuals and between individuals and collectives promote resilience and agency through fostering friendship, solidarity, collective visions of the future, and shared ideologies that are central to make meaning of suffering. Future research on resilience within political violence would advance literature on this topic by studying how individual resilience and community resilience work together to ensure wellbeing.

In addition to attending to the relationships between individuals and communities, this review also aimed to uncover other lessons for research and intervention within the fields of political violence and resilience. In the process of completing this review, it 
became clear that there is an emergent need to refine the conceptualizations of both political violence and resilience.

As evident in the literature reviewed, political violence is a broad category that encompasses many experiences including material deprivation; refugee experiences; exposure to sniper fire; being tear-gassed; bodily injury; disappearance, death or injury of loved ones; witnessing violence to others; and brain injury (Al-Krenawi, Graham, \& Sehwail, 2007; Basoglu et al., 2005; K. de Jong, et al., 2002; Garbarino \& Kostelny, 1996; Giacaman, Shannon, et al., 2007; Morina \& Ford, 2008; Punama $\square$ ki, et al., 2005; Saab, Chaaya, \& Doumit, 2003). Within political violence, the range of experiences may also vary according to a variety of time-dependent contextual variables, such as the move from acute to chronic, low-level violence; the post-conflict atmosphere; and the development stage of the individual, family or community (Betancourt, 2011; Montiel, 2000). Furthermore, effects of political violence vary alongside the subjective meaning of political violence, people's proximity to the violence, and the magnitude, duration, and chronicity of the conflict (Barber, 2008, 2009; Sagi-Schwartz, 2008). We also know that political violence coincides with hosts of other issues such as everyday stressors, neighborhood disorganization, poverty, domestic violence, and structural violence (Barber, 2001; Clark, et al., 2010; Farmer, 2004; Panter-Brick \& Eggerman, 2012).

Dissimilarities of experiences and effects within the relatively broad concept of political violence obviously affects a variation among required coping methods, as the most salient resources for adapting to stress may change according to dimensions of the stressor (Haj-Yahia, 2007; Macksoud \& Aber, 1996). For instance, factors that might be protective during acute political violence may not be protective once the threat of 
violence is not imminently present (Punama $\square$ ki, et al., 2001). To determine the pathways through which political violence influences wellbeing, continued efforts are needed in research to study political violence and resilience over time with longitudinal studies, to disentangle the various factors such as parenting, age, gender, and individual skills that shape how political violence is experienced, and to determine how to incorporate other co-existing factors such as experiences of poverty and everyday stressors into analyses about political violence.

As with the broader field of resilience, findings from this review demonstrate the lack of clarity and consistency about how resilience is operationalized on both individual and community levels. For instance, within the quantitative studies, some authors "measured" individual resilience using a scale (Laor, et al., 2006; Lee, et al., 2008), while others used behavioral or mental health outcomes to indicate individual resilience (Garbarino \& Kostelny, 1996; V. Khamis, 1993; Kuterovac-Jagodic, 2003). Attributes and skills, on both the individual and collective level, might simultaneously be indicators of resilience and also protective variables that build resilience.

Political violence and resilience are both issues that include constellations of factors that (1) are mutually influencing, (2) occur over time, (3) vary along many dimensions, including cultural, historical, and geographical. These opportunities within the study of political violence and resilience underscore the importance of drawing on a diversity of methods to build a body of scholarship around this important issue. The findings of this review illustrate the importance of studies that employ longitudinal methods, mixed methods designs, and analyses modeled on social ecological frameworks (Barber, 2008; Betancourt, 2011; Cummings, et al., 2009; Eric F. Dubow, et al., 2009). 
Results of this review also demonstrate that the work of conceptualizing resilience at the community level in particular is a relatively new frontier, with a lot of ambiguity regarding what signifies community resilience (Rutter, 2012). For instance, Chandra (2011) examined the concept of community resilience in relationship to national disasters, using literature reviews and focus groups, and identified these indicators of the community resilience: community engagement (including neighborhood cohesion); partnership among organizations; local leadership that works alongside state and federal governments; community health and access to health services; rapid restoration of services and social networks; and financial resiliency of families and businesses (Chandra, 2011). Other scholars suggest using a high and relatively equal level of "population wellness" (defined as mental and behavioral health, role functioning, and quality of life) to indicate community resilience, noting this outcome is easily differentiated from the resources within communities that build resilience, could easily be monitored, and should reflect how well emergency management systems are functioning (F. Norris, et al., 2008). Still others suggest the continuation of everyday life (such as large numbers of children remaining in school or the absence of disease outbreaks or social unrest) amidst considerable stressors of political violence indicate community resilience (Nuwayhid, et al., 2011; Panter-Brick \& Eggerman, 2012).

The development of societal-level variables (and in particular, those sensitive to issues like religion and culture) to measure resilience on a collective level remains to be done (Panter-Brick \& Eggerman, 2012), and will require innovative and systematic methods for creating and refining indicators. For instance, Sherrieb et al. (2010) conducted a comprehensive search for, and then testing and validation of, indicators to 
create an index of community resilience capacities. The final index included indicators of economic development (including resource level, resource equity, and resource diversity) and social capital (including social support, social participation and community bonds); this effort illustrates how important systematic processes are with regards to conceptualizing community resilience. In another example, the four resources (technical, organizational, social and economic) and four properties (robustness, redundancy, resourcefulness and rapidity) of community resilience described by Tierney (2003) were developed by a multidisciplinary agency dedicated to addressing the effects of natural and human-made hazards, including political violence, on collective structures. One of their projects is to develop qualitative and quantitative frameworks to define community resilience. This collective effort demonstrates the importance of multi-disciplinary teams and mixed research methods in conceptualizing the concept of community resilience.

Finally, with regards to research implications, this review considered studies from around the world, and some, though not all, of these studies explicitly explored the particular cultural context of their study. As with resilience more generally, it is evident that, regarding both understanding and intervening in the problem of political violence, studies that put the role of culture and local knowledge in the fore provided the most contextually rich content (Panter-Brick \& Eggerman, 2012; Ungar, 2008). Political violence is a global problem, but the strategies to build of resilience within its wake requires very specific attention to cultural contexts (Ager, et al., 2005; Summerfield, 1999).

Findings from this review suggest several implications for practice. Given the usefulness of social support in building individual resilience, implications for practice 
based on our review also include the need for rebuilding on the collective level after (or during) political violence. This could include aiding individuals in their use of social coping behaviors; rapidly reinstating structures for daily activities that foster a sense of normalcy through re-opening of schools and places of work; establishing or reestablishing opportunities for and norms around individuals' involvement in political activities; and instituting modes of communal accountability after atrocities, such as tribunals and truth commissions. Additionally, in light of the findings of this review with regards to the importance of the family in helping both child and adult survivors of political violence, interventions aimed at increased family functioning could prove useful in building resilience. Finally, many of the studies emphasized cognitive processes whereby survivors of political violence make meaning of their suffering; the importance of these processes for resilience should inform clinicians focused on more specifically on mental health services.

Translating knowledge from the growing literature about resilience within political violence into practical interventions is essential. Peltonen and Punamaki's multilevel review of interventions for children who have experienced political violence is an example (Peltonen \& Punama $\square$ ki, 2010). Incorporating new knowledge about individual and community resilience into intervention research related to the effects of political violence should continue, and should attend to interventions aimed not only at children, but also at adults, families, and communities.

This review has provided evidence about resilience in the face of political violence. Given the high proportion of political violence around the world, the existence of and possibilities for individual and collective resilience is heartening. However, the 
factors and processes that build resilience require a great deal of creativity, effort, and flexibility, and this represents a considerable strain on individuals, families, communities, and governments. Political violence often causes so much destruction on so many levels that it overburdens resources for resilience (Hobfoll, et al., 2011). While clearly research and practice should continue to build our understanding of resilience within political violence, it remains a central task to engage in primary prevention regarding this issue. The avoidance of political violence itself should be prioritized as a central task to ensure global health and well-being; there are growing numbers of practical examples of how scholars and practitioners are engaging in these efforts (J. T. de Jong, 2010; Hagopian, Ratevosian, \& deRiel, 2009). 


\section{References}

Agaibi, C. E. (2005). Trauma, PTSD, and Resilience: A Review of the Literature. Trauma, Violence, \& Abuse, 6(3), 195-216.

Ager, A., Strang, A., \& Abebe, B. (2005). Conceptualizing community development in war-affected populations: illustrations from Tigray. Community Development Journal, 40(2), 158-168.

Al-Krenawi, A., Graham, J. R., \& Sehwail, M. A. (2007). Tomorrow's players under occupation: an analysis of the association of political violent with psychological functioning and domestic violence, among Palestinian youth. The American journal of orthopsychiatry, 77(3), 427-433.

Almedom, A. M., \& Summerfield, D. (2004). Mental well-being in settings of 'complex emergency': an overview. Journal of Biosocial Science, 36(4), 381-388.

Baingana, F., Bannon, I., \& Thomas, R. (2005). Mental health and conflicts: Conceptual framework and approaches. In T. W. B. Human Development Network (Ed.), HNP Discussion Paper. Washington, DC: The World Bank.

Bar-Tal, D. (2001). Why Does Fear Override Hope in Societies Engulfed by Intractable Conflict, as It Does in the Israeli Society? Political Psychology, 22(3).

Bar-Tal, D., Jacobson, D., \& Freund, T. (1995). Security Feelings among Jewish Settlers in the Occupied Territories: A Study of Communal and Personal Antecedents. Journal of Conflict Resolution, 39(2), 353-377.

Barber, B. K. (1999). Political Violence, Family Relations, and Palestinian Youth Functioning. Journal of Adolescent Research, 14(2), 206-230.

Barber, B. K. (2001). Political violence, social integration, and youth functioning: Palestinian youth from the Intifada. Journal of Community Psychology, 29(3), 259-280.

Barber, B. K. (2008). Contrasting portraits of war: Youths' varied experiences with political violence in Bosnia and Palestine. International Journal of Behavioral Development, 32(4), 298.

Barber, B. K. (2009). Adolescents and war: how youth deal with political violence. Oxford; New York: Oxford University Press.

Basoglu, M., Livanou, M., \& Crnobaric, C. (2005). Psychiatric and Cognitive Effects of War in Former Yugoslavia: Association of Lack of Redress for Trauma and Posttraumatic Stress Reactions. JAMA: the Journal of the American Medical Association, 294(5), 580-590.

Basoglu, M., Livanou, M., Crnobaric, C., Franciskovic, T., Suljic, E., Duric, D., \& Vranesic, M. (2005). Psychiatric and Cognitive Effects of War in Former Yugoslavia: Association of Lack of Redress for Trauma and Posttraumatic Stress Reactions. JAMA: the Journal of the American Medical Association, 294(5), 580.

Basu, P. (2004). Iraq's public health infrastructure a casualty of war. Nature medicine, $10(2)$.

Berk, J. H. (1998). Trauma and resilience during war: a look at the children and humanitarian aid workers of Bosnia. Psychoanalytic Review, 85(4), 640-658.

Betancourt, T. S. (2011). Attending to the mental health of war-affected children: The need for longitudinal and developmental research perspectives. J. Am. Acad. 
Child Adolesc. Psychiatry Journal of the American Academy of Child and Adolescent Psychiatry, 50(4), 323-325.

Betancourt, T. S., Brennan, R. T., Rubin-Smith, J., Fitzmaurice, G. M., \& Gilman, S. E. (2010). Sierra Leone's Former Child Soldiers: A Longitudinal Study of Risk, Protective Factors, and Mental Health. Journal of the American Academy of Child and Adolescent Psychiatry, 49(6), 606-615.

Betancourt, T. S., \& Khan, K. T. (2008). The mental health of children affected by armed conflict: protective processes and pathways to resilience. International Review of Psychiatry, 20(3), 317-328.

Bonanno, G. A. (2004). Loss, trauma, and human resilience: have we underestimated the human capacity to thrive after extremely aversive events? The American Psychologist, 59(1), 20-28.

Chandra, A. (2011). Building community resilience to disasters a way forward to enhance national health security, from http://public.eblib.com/EBLPublic/PublicView.do?ptiID=683234

Clark, C. J., Everson-Rose, S. A., Suglia, S. F., Btoush, R., Alonso, A., \& Haj-Yahia, M. M. (2010). Association between exposure to political violence and intimatepartner violence in the occupied Palestinian territory: a cross-sectional study. The Lancet, 375(9711).

Cortes, L., \& Buchanan, M. (2007). The Experience of Columbian Child Soldiers from a Resilience Perspective. International Journal for the Advancement of Counselling, 29(1), 43-55.

Cummings, M. E., Goeke-Morey, M. C., Schermerhorn, A. C., Merrilees, C. E., \& Cairns, E. (2009). Children and Political Violence from a Social Ecological Perspective: Implications from Research on Children and Families in Northern Ireland. Clinical Child and Family Psychology Review, 12(1), 16-38.

de Jong, J. T. (2010). A public health framework to translate risk factors related to political violence and war into multi-level preventive interventions. Social Science \& Medicine, 70(1), 71-79.

de Jong, K., Mulhern, M., Ford, N., Simpson, I., Swan, A., \& van der Kam, S. (2002). Psychological trauma of the civil war in Sri Lanka. The Lancet, 359(9316), 15171518.

Dillenburger, K., Fargas, M., \& Akhonzada, R. (2008). Long-Term Effects of Political Violence: Narrative Inquiry Across a 20-Year Period. Qualitative Health Research, 18(10), 1312-1322.

Dubow, E. F., Huesmann, L. R., \& Boxer, P. (2009). A Social-Cognitive-Ecological Framework for Understanding the Impact of Exposure to Persistent EthnicPolitical Violence on Childrens Psychosocial Adjustment. Clinical Child \& Family Psychology Review, 12(2).

Dubow, E. F., Huesmann, L. R., Boxer, P., Shikaki, K., Landau, S., Gvirsman, S. D., \& Ginges, J. (2010). Exposure to conflict and violence across contexts: Relations to adjustment among Palestinian children. Journal of Clinical Child and Adolescent Psychology, 39(1), 103-116.

Eggerman, M., \& Panter-Brick, C. (2010). Suffering, hope, and entrapment: Resilience and cultural values in Afghanistan. Social Science and Medicine, 71(1). 
Elbedour, S., ten Bensel, R., \& Bastien, D. T. (1993). Ecological integrated model of children of war: individual and social psychology. Child Abuse and Neglect, 17(6).

Farmer, P. (2004). Political Violence and Public Health in Haiti. The New England Journal of Medicine, 350(15), 1483-1486.

Farwell, N. (2001). 'Onward through Strength': Coping and Psychological Support among Refugee Youth Returning to Eritrea from Sudan. Journal of Refugee Studies, 14(1), 43-69.

Farwell, N. (2004). War Rape: New Conceptualizations and Responses. Affilia, 19(4), 389-403.

Farwell, N., \& Cole, J. B. (2001). Community as a Context of Healing Psychosocial Recovery of Children Affected by War and Political Violence. International Journal of Mental Health, 30, 19-41.

Fazel, M., Reed, R. V., Panter-Brick, C., \& Stein, A. (2012). Mental health of displaced and refugee children resettled in high-income countries: risk and protective factors. The Lancet, 379(9812), 266-282.

Fluri, J. L. (2011). Bodies, bombs and barricades: geographies of conflict and civilian (in)security. Transactions of the Institute of British Geographers, 36(2).

Fraser, M., Kirby, L., \& Smokowski, P. (2004). Risk and resilience in childhood. In M. Fraser (Ed.), Risk and Resilience in Childhood: An ecological perspective. Washington, DC: NASW Press.

Garbarino, J., \& Kostelny, K. (1996). The effects of political violence on Palestinian children's behavior problems: A risk accumulation model. Child Development, 67(1), 33-45.

Geronimus, A. T., Hicken, M., Keene, D., \& Bound, J. (2006). "Weathering" and age patterns of allostatic load scores among blacks and whites in the United States. American journal of public health, 96(5), 826-833.

Giacaman, R. (2005). Coping with Conflict. Education for Health, 18(1), 2-4.

Giacaman, R., Mataria, A., Nguyen-Gillham, V., Abu Safieh, R., Stefanini, A., \& Chatterji, S. (2007). Quality of life in the Palestinian context: An inquiry in warlike conditions. Health Policy, 81, 68-84.

Giacaman, R., Shannon, H. S., Saab, H., Arya, N., \& Boyce, W. (2007). Individual and collective exposure to political violence: Palestinian adolescents coping with conflict. European Journal of Public Health, 17(4), 361-368.

Gibson, E. C. (2002). The impact of political violence: Adaptation and identity development in Bosnian adolescent refugees. Smith College Studies in Social Work, 73(1).

Guribye, E., Sandal, G. M., \& Oppedal, B. (2011). Communal proactive coping strategies among Tamil refugees in Norway: A case study in a naturalistic setting. International Journal of Mental Health Systems, 5.

Hagopian, A., Ratevosian, J., \& deRiel, E. (2009). Gathering in groups: peace advocacy in health professional associations. Academic medicine : journal of the Association of American Medical Colleges, 84(11).

Haj-Yahia, M. M. (2007). Challenges in studying the psychological effects of Palestinian children's exposure to political violence and their coping with this traumatic experience. Child Abuse \& Neglect, 31, 691-697. 
Haj-Yahia, M. M. (2008). Political violence in retrospect: Its effect on the mental health of Palestinian adolescents. International Journal of Behavioral Development, 32(4), 283-289.

Hernández, P. (2002). Resilience in Families and Communities: Latin American Contributions From the Psychology of Liberation. The Family Journal, 10(3), 334-343.

Herrenkohl, T. I. (2011). Resilience and protection from violence exposure in children : implications for prevention and intervention programs with vulnerable populations. In T. I. Herrenkohl (Ed.), Violence in context : current evidence on risk, protection, and prevention. New York: Oxford University Press.

Hobfoll, S. E., Hall, B. J., \& Canetti, D. (2012). Political violence, psychological distress, and perceived health: A longitudinal investigation in the Palestinian authority. Psychological Trauma: Theory, Research, Practice, and Policy 4(1), 9-21.

Hobfoll, S. E., Mancini, A. D., Hall, B. J., Canetti, D., \& Bonanno, G. A. (2011). The limits of resilience: Distress following chronic political violence among Palestinians. Social Science and Medicine, 72(8), 1400-1408.

Hoffman, M., \& Kruczek, T. (2011). A Bioecological Model of Mass Trauma: Individual, Community, and Societal Effects $\mathrm{E} \Sigma$. The Counseling Psychologist, 39(8), 1087-1127.

Hooberman, J., Rosenfeld, B., Rasmussen, A., \& Keller, A. (2010). Resilience in traumaexposed refugees: the moderating effect of coping style on resilience variables. The American Journal of Orthopsychiatry, 80(4), 557-563.

International Committee of the Red Cross (ICRC). (1949). Geneva Convention Relative to the Protection of Civilian Persons in Time of War (Fourth Geneva Convention). Retrieved from http://www.unhcr.org/refworld/docid/3ae6b36d2.html.

Janoff-Bulman, R. (1992). Shattered assumptions : towards a new psychology of trauma. New York; Toronto; New York: Free Press ; Maxwell Macmillan Canada ; Maxwell Macmillan International.

Jones, L., \& Kafetsios, K. (2005). Exposure to Political Violence and Psychological Well-being in Bosnian Adolescents: A Mixed Method Approach. Clinical Child Psychology and Psychiatry, 10(2), 157-176.

Kerestes, G. (2006). Children's aggressive and prosocial behavior in relation to war exposure: Testing the role of perceived parenting and child's gender. International journal of behavioral development, 30(3).

Khamis, V. (1993). Post-Traumatic Stress Disorder Among the injured of the Intifada. Journal of Traumatic Stress, 6(4), 555-559.

Khamis, V. (1993). Post-Traumatic Stress Disorder Among the Injured of the Intifada. Journal of Traumatic Stress, 6(4), 555-560.

Khamis, V. (1998a). Psychological distress and well-being among traumatized Palestinian women during the intifada. Social Science Medicine. , 46(8), 10331041.

Khamis, V. (1998b). Psychological distress and well-being among traumatized Palestinian women during the intifada. Social Science and Medicine, 46(8), 10331042. 
Khamis, V. (1998c). Psychological distress and well-being among traumatized Palestinian women during the intifada. . Social Science Medicine. , 46(8), 10331041.

Kimhi, S., \& Eshel, Y. (2009). Individual and public resilience and coping with longterm outcomes of war. J. Appl. Biobehav. Res. Journal of Applied Biobehavioral Research, 14(2), 70-89.

Kimhi, S., Eshel, Y., Zysberg, L., \& Hantman, S. (2010). Postwar winners and losers in the long run: Determinants of war related stress symptoms and posttraumatic growth. Community Ment. Health J. Community Mental Health Journal, 46(1), 10-19.

Klika, B., \& Herrenkohl, T. (under review). A Review of Developmental Research on Resilience in Maltreated Children. Trauma, Violence, \& Abuse.

Koopman, C. (1997). Political Psychology as a Lens for Viewing Traumatic Events. Political Psychology, 18(4), 831-848.

Kuterovac-Jagodic, G. (2003). Posttraumatic stress symptoms in Croatian children exposed to war: a prospective study. Journal of Clinical Psychology, 59(1), 9-25.

Landau, S., \& Saul, J. (2004). Family and community resilience in response to major disaster. In F. Walsh \& M. McGoldrick (Eds.), Living beyond loss : death in the family. New York: Norton.

Laor, N., Wolmer, L., Alon, M., Siev, J., Samuel, E., \& Toren, P. (2006). Risk and protective factors mediating psychological symptoms and ideological commitment of adolescents facing continuous terrorism. The Journal of nervous and mental disease, 194(4), 279-286.

Lazarus, R. S. (2000). Evolution of a model of stress, coping and discrete emotions. In V. H. Rice (Ed.), Handbook of stress, coping, and health : implications for nursing research, theory, and practice. Thousand Oaks, Calif.: Sage Publications.

Lee, H.-S., Brown, S., Mitchell, M., \& Schiraldi, G. (2008). Correlates of Resilience in the Face of Adversity for Korean Women Immigrating to the US. Journal of Immigrant and Minority Health, 10(5), 415-422.

Lykes, M. B., Beristain, C. M., \& Perez-Armioan, M. L. C. (2007). Political Violence, Impunity, and Emotional Climate in Maya Communities. Journal of Social Issues, 63(2), 369-385.

Lyons, R. F., Mickelson, K. D., Sullivan, M. J. L., \& Coyne, J. C. (1998). Coping as a Communal Process. Journal of Social and Personal Relationships, 15(5), 579-605.

Macksoud, M. S., \& Aber, J. L. (1996). The War Experiences and Psychosocial Development of Children in Lebanon. Child Development, 67(1), 70-88.

Martín-Baró, I., Aron, A., \& Corne, S. (1994). Writings for a liberation psychology. Cambridge, Mass.: Harvard University Press.

Martinez, M. A., \& Eiroa-Orosa, F. J. (2010). Psychosocial research and action with survivors of political violence in Latin America: methodological considerations and implications for practice. Intervention 8(1), 3-13.

Masten, A. S., \& Obradovic, J. (2008). Disaster Preparation and Recovery: Lessons from Research on Resilience in Human Development. Ecology \& Society, 13(1).

McEwen, B. S. (2000). Allostasis and Allostatic Load: Implications for Neuropsychopharmacology. Neuropsychopharmacology, 22(2), 108-124. 
Montiel, C. J. (2000). Political Trauma and Recovery in a Protracted Conflict: Understanding Contextual Effects. Peace and Conflict: Journal of Peace Psychology, 6(2), 93-111.

Morina, N., \& Ford, J. D. (2008). Complex sequelae of psychological trauma among Kosovar civilian war victims. The International journal of social psychiatry, 54(5), 425-436.

Nelson, B. S. (2003). Post-War Trauma and Reconciliation in Bosnia-Herzegovina: Observations, Experiences, and Implications for Marriage and Family Therapy. American Journal of Family Therapy, 31, 305-316.

Nguyen-Gillham, V., Giacaman, R., Naser, G., \& Boyce, W. (2008). Normalising the abnormal: Palestinian youth and the contradictions of resilience in protracted conflict. Health \& Social Care in the Community, 16(3), 291-298.

Norris, F., Stevens, S., Pfefferbaum, B., Wyche, K., \& Pfefferbaum, R. (2008). Community Resilience as a Metaphor, Theory, Set of Capacities, and Strategy for Disaster Readiness. American Journal of Community Psychology, 41(1-2), 1-2.

Norris, F. H., \& Kaniasty, K. (1996). Received and perceived social support in times of stress: a test of the social support deterioration deterrence model. Journal of Personality and Social Psychology, 71(3), 498-511.

Nuttman-Shwartz, O. (2012). Macro, meso and micro-perspectives of resilience during and after exposure to war. In M. Ungar (Ed.), The social ecology of resilience : a handbook of theory and practice. New York: Springer.

Nuwayhid, I., Zurayk, H., Yamout, R., \& Cortas, C. S. (2011). Summer 2006 war on Lebanon: A lesson in community resilience. Global Public Health, 6(5), 505-519.

Panter-Brick, C., \& Eggerman, M. (2012). Understanding culture, resilience, and mental health: The production of hope. In M. Ungar (Ed.), The social ecology of resilience : a handbook of theory and practice. New York: Springer.

Pedersen, D., Tremblay, J., Errazuriz, C., \& Gamarra, J. (2008). The sequelae of political violence: Assessing trauma, suffering and dislocation in the Peruvian highlands. Social Science \& Medicine, 67(2), 205-217.

Peltonen, K., \& Punama $\square$ ki, R. L. (2010). Preventive interventions among children exposed to trauma of armed conflict: A literature review. Aggress. Behav. Aggressive Behavior, 36(2), 95-116.

Pennebaker, J. W., Páez, D., \& Rimé, B. (1997). Collective memory of political events : social psychological perspectives. Mahwah, N.J.: Lawrence Erlbaum Associates.

Punama $\square$ ki, R. L., Komproe, I., Qouta, S., El-Masri, M., \& de Jong, J. T. (2005). The deterioration and mobilization effects of trauma on social support: Childhood maltreatment and adulthood military violence in a Palestinian community sample. Child Abuse \& Neglect, 29(4), 351.

Punama $\square$ ki, R. L., Qouta, S., \& El-Sarraj, E. (2001). Resiliency factors predicting psychological adjustment after political violence among Palestinian children. International journal of behavioral development 25, 256-267.

Qouta, S., Punama $\square$ ki, R. L., \& El Sarraj, E. (2003). Prevalence and determinants of PTSD among Palestinian children exposed to military violence. European Child and Adolescent Psychiatry, 12(6), 265-272.

Qouta, S., Punama $\square$ ki, R. L., Montgomery, E., \& Sarraj, E. E. (2007). Predictors of psychological distress and positive resources among Palestinian adolescents: 
Trauma, child, and mothering characteristics. Child Abuse and Neglect, 31(7), 699-717.

Qouta, S., Punama $\square$ ki, R. L., \& Sarraj, E. (1995). The impact of the peace treaty on psychological well-being: A follow up study of Palestinian children. Child Abuse and Neglect, 19(1), 1197-1208.

Robben, A. C. G. M. (2005). Political violence and trauma in Argentina. Philadelphia: University of Pennsylvania Press.

Rutter, M. (2012). Resilience: Causal pathways and social ecology. In M. Ungar (Ed.), The social ecology of resilience : a handbook of theory and practice. New York: Springer.

Saab, B. R., Chaaya, M., \& Doumit, M. (2003). Predictors of psychological distress in Lebanese hostages of war. Social Science \& Medicine, 57(7), 1249-1257.

Sagi-Schwartz, A. (2008). The well being of children living in chronic war zones: The PalestinianIsraeli case. International Journal of Behavioral Development, 32(4), 322-336.

Shalhoub-Kevorkian, N. (2006). Counter-Spaces as Resistance in Conflict Zones: Palestinian Women Recreating a Home. Journal of Feminist Family Therapy, 17(3-4), 109-141.

Sherrieb, K., Norris, F. H., \& Galea, S. (2010). Measuring Capacities for Community Resilience. Social Indicators Research, 99(2), 227-247.

Shinn, M., \& Toohey, S. M. (2003). Community Contexts of Human Welfare. Annual Review of Psychology, 54, 427.

Sidel, V. W. (2008). War, terrorism and the public's health. Medicine, Conflict, and Survival, 24.

Sidel, V. W., \& Levy, B. S. (2008). The health impact of war. International Journal of Injury Control and Safety Promotion, 15(4), 189-195.

Skidmore, M. (2003). Darker than Midnight: Fear, Vulnerability, and Terror Making in Urban Burma (Myanmar). American Ethnologist, 30(1), 5-21.

Summerfield, D. (1999). A critique of seven assumptions behind psychological trauma programmes in war-affected areas. Social Science and Medicine, 48(10), 14491462.

Summerfield, D. (2000). War and mental health: a brief overview. BMJ (Clinical research ed.), 321(7255), 232-235.

Taylor, L. K., Merrilees, C. E., Cairns, E., Shirlow, P., Goeke-Morey, M., \& Cummings, E. M. (2012). Risk and resilience: The moderating role of social coping for maternal mental health in a setting of political conflict. International Journal of Psychology International Journal of Psychology, 1-13.

Thabet, A. A., Ibraheem, A. N., Shivram, R., Winter, E. A., \& Vostanis, P. (2009). Parenting support and PTSD in children of a war zone. International Journal of Social Psychiatry, 55(3), 226-237.

Tierney, K. J. (2003). Conceptualizing and measuring organizational and and community resilience: Lessons from the Emergency Response Following the September 11,2001Attack on the World Trade Center. Paper presented at the University of Delaware Disaster Research Center. 
UNESCO. (2006). Director-General condemns new wave of killing of journalists in Iraq. UNESCO News Service. Retrieved from http://portal.unesco.org/ci/en/ev.phpURL_ID=22680\&URL_DO=DO_TOPIC\&URL_SECTION=201.html

UNESCO: International Program for the Development of Communication (IPDC). (2012). IPDC Decision on the safety of journalists and the issue of impunity. 28th IPDC Council session 22-23 March 2012: Retrieved from http://www.unesco.org/new/fileadmin/MULTIMEDIA/HQ/CI/CI/pdf/IPDC/ipdc2 8_safety_decision_final.pdf.

Ungar, M. (2008). Resilience across Cultures. British Journal of Social Work, 38(2), 218235.

Ungar, M. (2011a). Community resilience for youth and families: Facilitative physical and social capital in contexts of adversity. Children and Youth Services Review, 33(9), 1742-1748.

Ungar, M. (2011b). The social ecology of resilience: Addressing contextual and cultural ambiguity of a nascent construct. American Journal of Orthopsychiatry, 81(1), 117.

United Nations Development Program (UNDP). (2012). Political violence in West Africa: A critical analysis of the role of parlimentarians and political parties. In United Nations Development Program (UNDP) (Ed.). New York NY.

United Nations Population Fund. (2007). Checkpoints Compound the Risks of Childbirth for Palestinian Women. Retrieved from http://www.unfpa.org/news/news.cfm?ID=972

Ursano, R. J., Fullerton, C. S., \& McCaughey, B. G. (1994). Trauma and Disaster. In R. J. Ursano, B. G. McCaughey \& C. S. Fullerton (Eds.), Individual and community responses to trauma and disaster: the structure of human chaos. Cambridge; New York, NY USA: Cambridge University Press.

Voils, C., Sandelowski, M., Barroso, J., \& Hasselblad, V. (2008). Making Sense of Qualitative and Quantitative Findings in Mixed Research Synthesis Studies. Field Methods, 20(1), 3-25.

Walsh, F. (2007). Traumatic Loss and Major Disasters: Strengthening Family and Community Resilience. Family Process, 46(2), 207-227.

World Health Organization. (2008). Closing the gap in a generation: Health equity through action on the social determinants of health. In Commission on Social Determinants of Health (Ed.).

World Health Organization (WHO). (2002). World Report on Violence and Health. Geneva: WHO.

Wyche, K. F., Pfefferbaum, R. L., Pfefferbaum, B., Norris, F. H., Wisnieski, D., \& Younger, H. (2011). Exploring Community Resilience in Workforce Communities of First Responders Serving Katrina Survivors. American Journal of Orthopsychiatry, 81(1).

Zraly, M., \& Nyirazinyoye, L. (2010). Don't let the suffering make you fade away: an ethnographic study of resilience among survivors of genocide-rape in southern Rwanda. Social Science \& Medicine, 70(10), 1656-1664.

Zwi, A., \& Ugalde, A. (1989). Towards an epidemiology of political violence in the Third World. Social Science \& Medicine, 28(7), 633-642. 
Table 1: Summary of studies: locations, data sources, and methods*

Table 2: Critical Findings 


\begin{tabular}{|c|c|c|c|c|c|c|}
\hline $\begin{array}{l}\text { Author, type of violence } \\
\text { (characterized by author, if } \\
\text { given) \& study location }\end{array}$ & Data source & 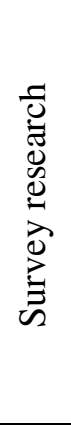 & 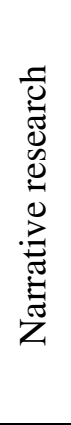 & 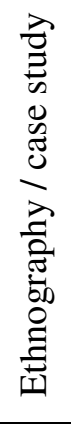 & 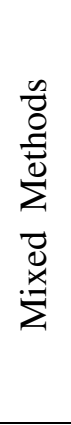 & 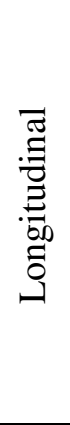 \\
\hline \multicolumn{7}{|c|}{ Individual resilience within the context of political violence } \\
\hline $\begin{array}{l}\text { Barber, } 1999 \& 2001 \\
\text { Political violence } \\
\text { Palestine }\end{array}$ & 7000 Palestinian $9^{\text {th }}$ graders & $\mathrm{x}$ & & & & \\
\hline $\begin{array}{l}\text { Barber, } 2008 \\
\text { War and Political violence } \\
\text { Palestine and Bosnia }\end{array}$ & $\begin{array}{l}\text { Palestine: same as above }+ \text { an immersive, } \\
\text { ethnographic phase }+ \text { follow up surveys } \\
(\mathrm{N}=900) \\
\text { Bosnia: several dozen youth }+ \text { surveys }(\mathrm{N}=600)\end{array}$ & $\mathrm{x}$ & & $\mathrm{x}$ & $\mathrm{x}$ & \\
\hline $\begin{array}{l}\text { Berk, } 1998 \\
\text { War } \\
\text { Bosnia }\end{array}$ & $\begin{array}{l}\text { Site for case study development and data } \\
\text { collection: Experiences with Bosnian children } \\
\text { and humanitarian aid workers }\end{array}$ & & & $\mathrm{x}$ & & \\
\hline $\begin{array}{l}\text { Betancourt, et al., } 2010 \\
\text { Civil war child soldiers } \\
\text { Sierra Leone }\end{array}$ & $\begin{array}{l}260 \text { former Sierra Leonean child soldiers (ages } \\
10 \text { - } 17 \text { at baseline) }\end{array}$ & $\mathrm{x}$ & & & & $\mathrm{x}$ \\
\hline $\begin{array}{l}\text { Cortes \& Buchanan, } 2007 \\
\text { Internal armed conflict child } \\
\text { soldiers } \\
\text { Colombia }\end{array}$ & $\begin{array}{l}6 \text { Colombian former child soldiers (ages 12-18) } \\
\text { identified as resilient }\end{array}$ & & $\mathrm{X}$ & & & \\
\hline $\begin{array}{l}\text { Cummings, et al. } 2009 \\
\text { Political violence } \\
\text { Northern Ireland } \\
\end{array}$ & 700 mother-child dyads & $\mathrm{x}$ & & & & $\mathrm{x}$ \\
\hline $\begin{array}{l}\text { Dubow, et al., } 2010 \\
\text { Ethnic-political violence } \\
\text { Palestine }\end{array}$ & $\begin{array}{l}600 \text { Palestinian children; } 3 \text { age cohorts: } 8,11 \text {, } \\
14\end{array}$ & $\mathrm{x}$ & & & & \\
\hline $\begin{array}{l}\text { Eggerman \& Panter-Brick, } 2010 \\
\text { War } \\
\text { Afghanistan }\end{array}$ & $\begin{array}{l}1011 \text { Afghan children (ages 11-16) \& adult } \\
\text { caregivers; systematic, random selection in } \\
\text { schools }\end{array}$ & $\mathrm{x}$ & $\mathrm{x}$ & & $\mathrm{x}$ & \\
\hline $\begin{array}{l}\text { Farwell, } 2001 \\
\text { War } \\
\text { Eritrea }\end{array}$ & $\begin{array}{l}33 \text { youth (ages } 13-20 \text { ); systematic sample, } \\
\text { stratified by ethnicity }\end{array}$ & & $\mathrm{x}$ & & & \\
\hline $\begin{array}{l}\text { Garbarino \& Kostelny, } 1996 \\
\text { Political violence } \\
\text { Palestine }\end{array}$ & $\begin{array}{l}150 \text { Palestinian mothers and their children (ages } \\
6-9 \& 12-15)\end{array}$ & $\mathrm{x}$ & & & & \\
\hline $\begin{array}{l}\text { Giacaman, } 2005 \\
\text { Political violence } \\
\text { Palestine }\end{array}$ & $\begin{array}{l}\text { Site for case study development and data } \\
\text { collection: Community public health research } \\
\text { agency within major Palestinian university }\end{array}$ & & & $\mathrm{x}$ & & \\
\hline $\begin{array}{l}\text { Giacaman, } 2007 \\
\text { Political violence } \\
\text { Palestine }\end{array}$ & 3415 youth (ages $15-18$ ) & $\mathrm{x}$ & & & & \\
\hline
\end{tabular}




\begin{tabular}{|c|c|c|c|c|c|}
\hline $\begin{array}{l}\text { Gibson, } 2002 \\
\text { War } \\
\text { Bosnian refugees in U.S. }\end{array}$ & five Bosnian adolescent refugees (ages 14-18) & & $\mathrm{x}$ & & \\
\hline $\begin{array}{l}\text { Haj-Yahia, } 2008 \\
\text { Political violence } \\
\text { Palestine }\end{array}$ & $1,185$ youth (ages $14-20)$ & $\mathrm{x}$ & & & \\
\hline $\begin{array}{l}\text { Hernández, } 2002 \\
\text { Political violence Colombia }\end{array}$ & $\begin{array}{l}8 \text { adult Colombian human rights activists and } \\
\text { survivors of political violence }\end{array}$ & & $\mathrm{x}$ & & \\
\hline $\begin{array}{l}\text { Hobfoll, } 2011 \\
\text { Political violence } \\
\text { Palestine }\end{array}$ & $\begin{array}{l}1196 \text { Palestinian adult residents of the West } \\
\text { Bank, Gaza, and East Jerusalem }\end{array}$ & $\mathrm{x}$ & & & $\mathrm{x}$ \\
\hline $\begin{array}{l}\text { Hooberman, } 2010 \\
\text { Torture survivors } \\
\text { New York }\end{array}$ & $\begin{array}{l}75 \text { adult torture survivors (age } M=33 \text { ) who are } \\
\text { immigrant, refugee, or asylum seekers in New } \\
\text { York (most from Africa or Asia) }\end{array}$ & $\mathrm{x}$ & & & \\
\hline $\begin{array}{l}\text { Jones \& Kafetsios, } 2005 \\
\text { War } \\
\text { Bosnia }\end{array}$ & $\begin{array}{l}337 \text { Bosnian adolescents \& additional sub- } \\
\text { sample of } 40 \text { (ages 13-15) }\end{array}$ & $\mathrm{x}$ & $\mathrm{x}$ & $\mathrm{x}$ & \\
\hline $\begin{array}{l}\text { Kerestes, } 2006 \\
\text { War } \\
\text { Croatia }\end{array}$ & 694 children & $\mathrm{x}$ & & & \\
\hline $\begin{array}{l}\text { Khamis, } 1993 \\
\text { Political violence } \\
\text { Palestine }\end{array}$ & $\begin{array}{l}\text { 120 males with Intifada related injuries (age } M= \\
\text { 21) }\end{array}$ & $\mathrm{x}$ & & & \\
\hline $\begin{array}{l}\text { Khamis, } 1998 \\
\text { Political violence } \\
\text { Palestine }\end{array}$ & 305 Palestinian women & $\mathrm{x}$ & & & \\
\hline $\begin{array}{l}\text { Kimhi, } 2009 \\
\text { War } \\
\text { Kiryat Shemona }\end{array}$ & 870 adults & $\mathrm{x}$ & & & \\
\hline $\begin{array}{l}\text { Kimhi, } 2010 \\
\text { War } \\
\text { Kiryat Shemona }\end{array}$ & $\begin{array}{l}821 \text { adolescents (ages } 12-18 \text { ); } 870 \text { adults (ages } \\
18-85 \text { ) }\end{array}$ & $\mathrm{x}$ & & & \\
\hline $\begin{array}{l}\text { Kuterovac-Jagodic, } 2003 \\
\text { War } \\
\text { Croatia }\end{array}$ & 252 children (age $M=10$ ) & $\mathrm{x}$ & & & $\mathrm{x}$ \\
\hline $\begin{array}{l}\text { Laor, } 2006 \\
\text { War } \\
\text { Israelis in Tel-Aviv/Jaffa; West } \\
\text { Bank }\end{array}$ & 1105 youth (ages $12-16)$ & $\mathrm{x}$ & & & \\
\hline $\begin{array}{l}\text { Lee, et al. } 2008 \\
\text { war } \\
\text { Koreans in America }\end{array}$ & $\begin{array}{l}\text { Korean mothers }(\mathrm{N}=200) \& \text { daughters }(\mathrm{N}= \\
170) \text { Findings from mothers included here } \\
\text { because authors note most lived through } 2 \text { wars. }\end{array}$ & $\mathrm{x}$ & & & \\
\hline $\begin{array}{l}\text { Lykes et al. } 2007 \\
\text { Internal armed conflict and } \\
\text { massive political repression } \\
\text { Guatemala }\end{array}$ & $\begin{array}{l}\text { Study 1: focus groups ( } 16 \text { total; total } \mathrm{N}=305) \\
\text { with } 4 \text { populations: internally displaced }(4) ; \\
\text { political refugees (4); repressed by military }(5) \text {; } \\
\text { returnees (3) Study 2: victims of community } \\
\text { massacre: individuals (N=56); } 7 \text { groups (total } \\
\mathrm{N}=74 \text { ) Study 3: Mayan women }(\mathrm{N}=20)\end{array}$ & & $\mathrm{x}$ & & \\
\hline
\end{tabular}




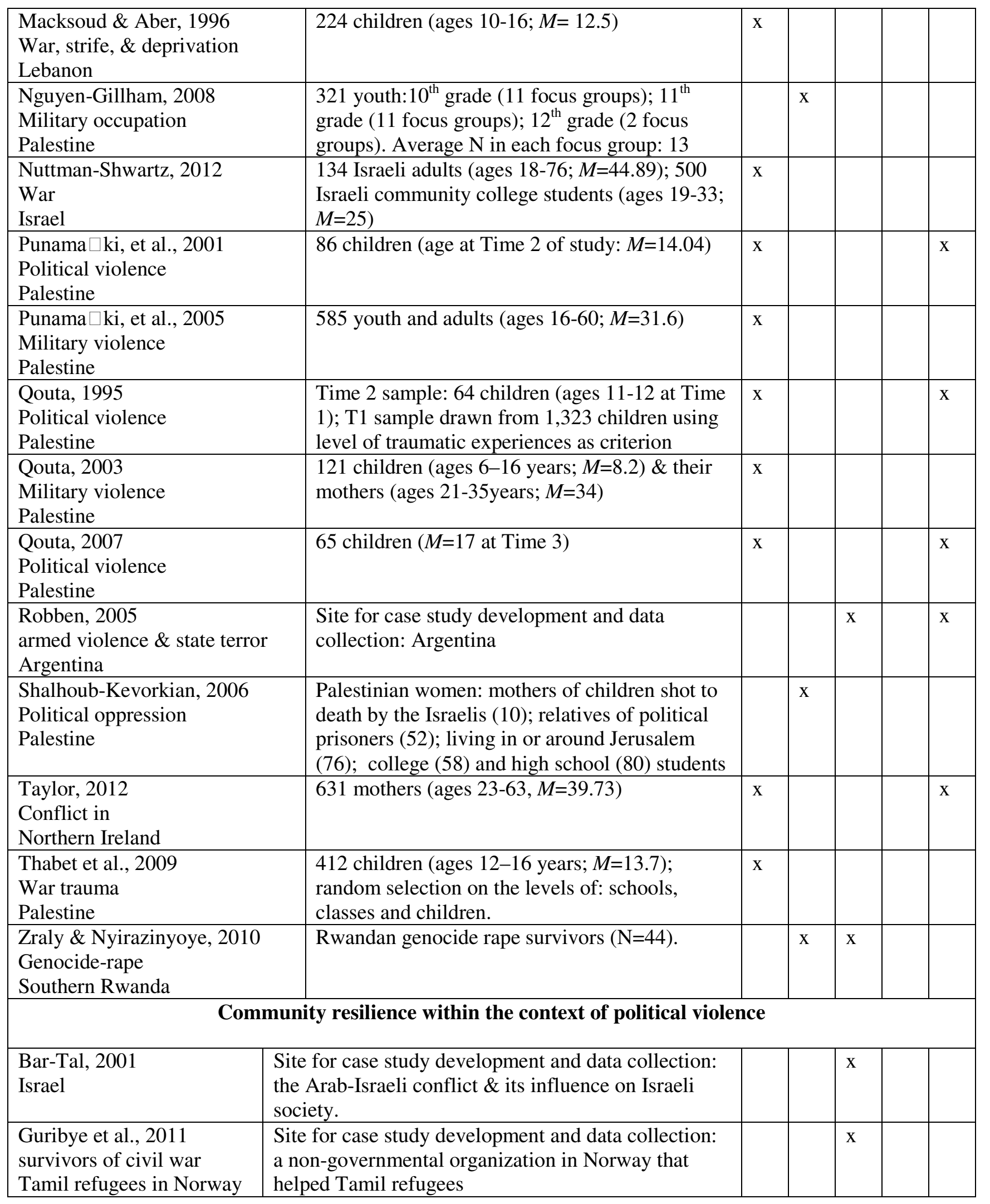




\begin{tabular}{|c|c|c|c|c|}
\hline $\begin{array}{l}\text { Landau \& Saul, } 2004 \\
\text { Terrorism \& repression } \\
\text { New York; Buenas Aires }\end{array}$ & $\begin{array}{l}\text { Sites for case study development and data collection: } \\
\text { New York post- } 9 / 11 \text { terrorist attacks; } \\
\text { "disappearances" of dissidents in Buenas Aires. }\end{array}$ & & $\mathrm{X}$ & \\
\hline $\begin{array}{l}\text { Pennebaker et al., } 1997 \\
\text { Mass events (i.e., wars) } \\
\text { Global }\end{array}$ & $\begin{array}{l}\text { Methods \& sites range from natural observation to } \\
\text { controlled laboratory experiments, looking at } \\
\text { collective memory }\end{array}$ & & & $\mathrm{x}$ \\
\hline $\begin{array}{l}\text { Nuwayhid, } 2011 \\
\text { War } \\
\text { Lebanon }\end{array}$ & $\begin{array}{l}\text { Site for case study development and data collection: } \\
\text { Voluntary relief efforts at displacement centers } \\
\text { during and following the war }\end{array}$ & & $\mathrm{X}$ & \\
\hline $\begin{array}{l}\text { Tierney, } 2003 \\
\text { Mass trauma: } 2001 \text { attack } \\
\text { in New York }\end{array}$ & $\begin{array}{l}\text { Site for case study development and data collection: } \\
\text { The response following the September } 11 \text { terrorist } \\
\text { attack on the World Trade Center }\end{array}$ & & $\mathrm{X}$ & \\
\hline $\begin{array}{l}\text { Wyche et al., } 2011 \\
\text { Mass trauma: Hurricane } \\
\text { Katrina in New Orleans }\end{array}$ & $\begin{array}{l}\text { Site for case study development and data collection: } \\
\text { First-responder workplace organizations serving } \\
\text { Hurricane Katrina survivors }\end{array}$ & $\mathrm{x}$ & $\mathrm{x}$ & \\
\hline $\begin{array}{l}\text { Walsh, } 2007 \\
3 \text { sites of mass trauma in } \\
\text { the United States }\end{array}$ & $\begin{array}{l}\text { Sites: a shooting in a neighborhood, a Chicago-based } \\
\text { project for refugees, the Oklahoma City Bombing, } \\
\text { and World Trade Center Attacks. }\end{array}$ & & $\mathrm{x}$ & \\
\hline
\end{tabular}

* Type of method indicated for studies is not mutually exclusive; if the study used multiple methods, all methods are represented in the table.

Explanations for classifications: Survey research: written or oral surveys/questionnaires; Narrative research: focus groups, interviews, other narrative methods (e.g. illustrations and discussions); Ethnography or Case

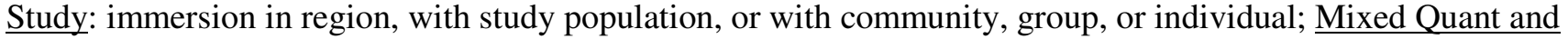
Qual Methods: Authors use both quantitative and qualitative methods; Longitudinal: Authors collected data (quantitative and/or qualitative-or both) from same study population at more than one timepoint. 
Table 2: Critical Findings

- Individual resilience and political violence: children

$\circ$ Evidence appears mixed on the role of age and gender as a source of protection within political violence. Studies indicate that experiences within political violence may differ based on gender and age.

- Other demographic factors that may be protective for children who experience political violence include parents' mental health, level of education, and status of occupation, and the regions in which children reside.

- Children's values (religious conviction), temperament and emotional orientation (sense of hope, sense of agency, future orientation), and skills (social intelligence, empathy, and affect regulation) may all provide protection for children experiencing political violence.

- Protective factors differ at various stages and degrees of political violence.

- Individual resilience and political violence: adults

- There is little evidence about the role of demographic factors as a source of protection for adults who experience political violence.

○ Religious conviction, self-esteem, optimism, a sense of hope, and engaging in processes of making meaning from the violence may all build resilience for adults facing political violence.

- The role of resources available in the environment for resilience within political violence

- Family resources such as positive family functioning, family stability, family unity, family hardiness and family cohesion appear important for both children and adults.

- Social resources such as the opportunity to be involved in school, work, or political action are important for individuals.

- The existence of and ability to access social support is a central way both children and adults cope with political violence.

- For children, the existence of role models and supportive, loving adults helps build resilience.

- Opportunities for processes of accountability after political violence through communal activities like tribunals and truth commissions take on particular importance in terms of resilience.

- Culture, particularly cultural ceremonies and values, is an important resource that promotes resiliency.

- Community resilience and political violence

- Community resilience within the context of political violence is increasingly studied and discussed

- Like individual resilience, community resilience has been described as a process, not a trait or an end product. As with individual resilience, there are certain traits, capacities and emotional orientations towards hardship that enable the process of resilience.

- The emotional orientations that appear to build resilience on the community level include a collective sense of hope, agency, altruism, trust, and patterns of interdependence. 
- Community characteristics, including collective identity, community cohesion, and a hardiness borne of previous experience with violence also build the potential for resilience.

- Resources that build community resilience include educational and health service networks run by trusted leadership, as well as technical, organizational, social and economic resources.

- Formal and informal networks build community resilience.

- Activities related to collective memory of the trauma of political violence also appear to be important in building community resilience.

Table 3: Implications for practice, policy, and research

- Understanding both individual and community resilience (and the dynamic relationship between these two) is central for practice, policy and research on the topic of political violence.

- There is a growing need to refine our conceptualizations of both political violence and resilience.

- As with resilience more generally, it is evident that it is essential to put the role of culture and local knowledge in the fore when examining and intervening in the problem of political violence.

- Given the usefulness of social support in building individual resilience, implications for practice based on our review include the need for rebuilding on the collective level in the wake of political violence.

- Building resilience in the face of political violence represents a considerable strain on individuals, families, communities and governments. While research and practice should continue to build our understanding of resilience within political violence the prevention of political violence itself should be prioritized as a central task. 